\title{
SINKRONISASI KEBIJAKAN KERJASAMA ANTAR DAERAH DALAM DIVESTASI SAHAM PT NEWMONT NUSA TENGGARA*
}

\author{
Lalu Wira Pria S.**
}

Bagian Hukum Bisnis, Fakultas Hukum Universitas Mataram, Mataram

Jalan Majapahit No. 62 Mataram, Nusa Tenggara Barat 83125

\begin{abstract}
Divestment of PT NNT is located in the province of NTB, involving three Local Government ie Province, $K S B$, and Sumbawa regency, and have collaborated to form PT DMB is partnering with PT MC to acquire PT NNT. As a result of that happening is disagreement between the three regions in issuing policies on regional cooperation. To that end, the synchronization policy research cooperation between the three parties, including the central government needs to be done to avoid disharmony between regions that are not infrequently involve the community.
\end{abstract}

Keywords: divestment, regional cooperation, synchronization.

\section{Intisari}

Divestasi saham PT NNT yang berlokasi di NTB, melibatkan tiga Pemerintah Daerah yaitu Provinsi NTB, KSB, dan Kabupaten Sumbawa, dan telah bekerjasama membentuk PT DMB yang bermitra dengan PT MC untuk mengakuisisi saham PT NNT. Akibat yang terjadi adalah pertentangan antar ketiga daerah tersebut dalam mengeluarkan kebijakan menyangkut kerjasama daerah. Untuk itu, penelitian sinkronisasi kebijakan kerjasama antara ketiga pihak tersebut termasuk dengan Pemerintah Pusat perlu dilakukan untuk menghindari terjadinya disharmonisasi antara daerah yang tidak jarang melibatkan masyarakat.

Kata Kunci: divestasi, kerjasama daerah, sinkronisasi.

\section{Pokok Muatan}

A. Latar Belakang 44

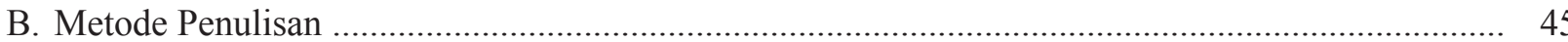

C. Hasil Penelitian dan Pembahasan ........................................................................................... 45

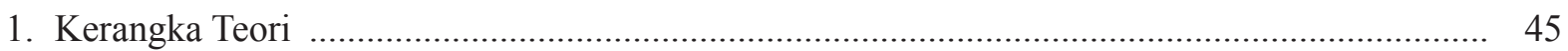

2. Kepemilikan Saham pada PT Newmont Nusa Tenggara (PT NNT) ........................................ 46

3. Kebijakan Daerah dalam Divestasi …….......................................................................... 48

4. Sikap Pemerintah Pusat terhadap Sisa Saham 7\% Tahun 2010 .............................................. 50

5. Kedudukan Pusat Investasi Pemerintah (PIP) dan Sengketa antar Kewenangan Lembaga

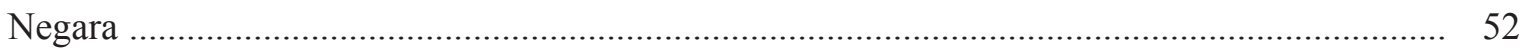

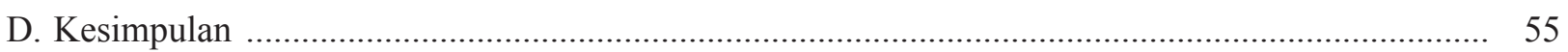

Hasil Penelitian Magister Ilmu Hukum Universitas Mataram Tahun 2013.

Alamat korespondensi : wip.intan@gmail.com 


\section{A. Latar Belakang}

Berdasarkan Putusan Arbitrase Internasional tanggal 31 Maret 2009, ${ }^{1}$ bahwa PT Newmont Nusa Tenggara (PT NNT) wajib menyerahkan 3\% divestasi saham tahun 2006 dan 7\% divestasi saham tahun 2007 kepada Pemerintah Daerah NTB, Kabupaten Sumbawa Barat (KSB), dan Kabupaten Sumbawa (KS) atau kepada perusahaan yang ditunjuk oleh Pemerintah Daerah. Sedangkan untuk divestasi 7\% saham tahun 2008, PT NNT wajib mentransfer saham kepada Pemerintah, yaitu Pemerintah RI atau Pemerintah Daerah atau perusahaan yang ditunjuk oleh Pemerintah RI atau Pemerintah Daerah, dan untuk merealisasi kewajiban ini Putusan Arbitrase memberi waktu selama 180 hari kepada PT NNT.

Berdasarkan Pasal 24 ayat (4) Kontrak Karya $^{2}$ bahwa PT NNT diharuskan melepaskan 51\% saham asingnya (divestasi) kepada pihak nasional (Pemerintah Daerah dan Pemerintah Pusat). Pada saat penandatanganan Kontrak Karya bahwa sebanyak $20 \%$ dari saham tersebut sudah dikuasai nasional yaitu oleh PT Pukuafu Indah, sehingga masih tersisa $31 \%$ yang harus didivestasikan, dan sesuai kontrak karya, jadwal divestasi 31\% saham tersebut adalah Maret 2006 (3\%), Maret 2007 (7\%), Maret 2008 (7\%), dan Maret 2010 (7\%). Untuk keperluan divestasi saham tersebut, maka tiga Pemerintah Daerah (Pemerintah Provinsi NTB, Pemerintah Kabupaten Sumbawa Barat (KSB), dan Kabupaten Sumbawa) telah membuat Perjanjian Kerjasama Nomor 415.4/229/KESDA, Nomor 500/70/EKBANG/2009, Nomor 21 Th $2009^{3}$ melalui pembentukan sebuah perusahaan yang bernama PT Daerah Maju Bersaing (PT DMB). Kemudian PT DMB menggandeng investor mitra PT Multi Capital (PT MC) yang merupakan anak perusahaan PT Bumi Resources Tbk untuk mengakuisisi saham PT NNT.

Pembentukan PT DMB yang didasarkan pada Peraturan Daerah No. 4 Tahun 20104, merupakan badan usaha milik daerah dengan tanggung jawab pengelolaan aset yang cukup besar, di samping itu juga memiliki tanggung jawab sosial (CSR) dan pengembangan masyarakat (CD). Alokasi untuk kepentingan ini dalam Pasal 32 ditentukan diambil dari laba bersih yang diperuntukkan dari cadangan umum $2 \%$ dan cadangan tujuan 1,5\%. Berdasarkan Perjanjian Kerjasama dan Peraturan Daerah tersebut di atas bahwa ketiga daerah yang diwakili oleh PT DMB akan melakukan upaya terbaik untuk melakukan pembelian saham divestasi PT NNT sampai $31 \%$, artinya termasuk di dalamnya adalah saham 7\% tahun 2010. Namun sampai saat ini belum terlihat, padahal ini merupakan bagian dari tanggung jawab PT DMB yang sangat substantif berkaitan dengan keberadaan perusahaan tersebut sebagai BUMD di NTB.

Adanya pihak yang tidak komitmen untuk memiliki saham secara bersama-sama terutama berkaitan kepemilikan saham 7\% tahun 2010, semakin mempersulit terciptanya kerjasama antar ke-3 pemerintah daerah (termasuk dengan pemerintah pusat). Sementara jadwal divestasi 2010 yang seharusnya sudah rampung, masih belum selesai dan menemukan jalan buntu akibat keinginan yang berbeda dari Pemerintah Pusat dan Pemerintah Daerah, dan kondisi ini telah menyebabkan jadwal divestasi tersebut menjadi tertunda. Perebutan divestasi 7\% tahun 2010 oleh Pemerintah Pusat dan Pemerintah Daerah masih terus berlangsung

Sengketa antara Pemerintah RI dan PT NNT dengan arbitrator: Dr. Robert Briner sebagai ketua, dengan anggota yaitu Prof. Muthucumaraswamy Sornarajah dan Stephen M. Schwebel.

Kontrak Karya antara Pemerintah RI dan PT NNT tanggal 2 Desember 1986.

Dalam Pasal 2 Perjanjian Kerjasama antara Gubernur NTB, Bupati Sumbawa Barat dan Bupati Sumbawa Nomor 415.4/229/KESDA, Nomor 500/70/EKBANG/2009, Nomor 21 Tahun 2009 tentang Pendirian Perusahaan Patungan yang akan diberi nama PT Daerah Maju Bersaing, disebutkan bahwa perjanjian kerjasama bertujuan untuk mendirikan perusahaan patungan yang akan diberi nama PT DMB, yang akan dipergunakan sebagai badan hukum untuk melakukan pembelian saham divestasi PT NNT, baik untuk saham divestasi periode tahun 2006 maupun saham divestasi periode tahun 2007 dan sepanjang dimungkinkan berdasarkan ketentuan hukum yang berlaku, PT DMB akan melakukan upaya terbaik untuk melakukakan pembelian saham divestasi PT NNT sampai 31\%, sebagaimana ditentukan dalam Kontrak Karya PT NNT dengan Pemerintah RI.

Peraturan Daerah Nomor 4 Tahun 2010 tentang Perseroan Terbatas Daerah Maju Bersaing (Lembaran Daerah Provinsi Nusa Tenggara Barat Tahun 2010 Nomor 27, Tambahan Lembaran Daerah Nomor 57), ditetapkan pada tanggal 27 Mei 2010. 
dan menjadi berita utama di berbagai media lokal maupun nasional. Pemerintah Pusat, melalui Menteri Keuangan, telah melakukan berbagai upaya guna membeli Saham PT NNT (divestasi 7\% tahun 2010) senilai US\$271,6 juta. Di lain pihak, Pemerintah Daerah gencar menuntut agar 7\% saham divestasi tersebut diserahkan ke Pemerintah Daerah. Bertolak dari berbagai permasalahan akibat tidak sinkronnya kebijakan dalam divestasi PT NNT, maka perlu dilakukan kajian secara sistematik dan komprehensif sehingga kepastian hukum dalam investasi dapat terwujud di Indonesia.

\section{B. Metode Penelitian}

Berdasarkan substansi permasalahan yang akan dikaji dalam penelitian ini, maka penelitian ini adalah penelitian hukum, yang memuat analisis dogmatik, teoritis, dan filosofis, yakni suatu penelitian yang terutama mengkaji permasalahan berdasarkan aturan-aturan hukum positif, teoriteori yang relevan, dan prinsip-prinsip hukum umum, serta melakukan ekposisi sistematis, dan analisis keterkaitan antara aturan-aturan hukum ${ }^{5}$ dalam bidang investasi, dengan demikian dalam penelitian ini menggunakan beberapa pendekatan, yaitu: statute approach ${ }^{6}$, conceptual approach ${ }^{7}$, dan historical approach. ${ }^{8}$

\section{Hasil Penelitian dan Pembahasan 1. Kerangka Teori}

M. Sornarajah ${ }^{9}$ mendefinisikan investasi asing (foreign investment): "The transfer of tangible or intangible assets from one country to another for the purpose of use in that country to generate wealth under the total or partial control of the owner of the assets". Sementara Pritchard ${ }^{10}$ mendefinisikan investasi asing sebagai:

The capital invested in an enterprise or an asset by a non-resident which gives the investor a significant influence (either potentially or actually exercised) over the key policies of the enterprise or over the use of the asset. FDI may involve the acquisition of an existing enterprise, the establishment of a new enterprise, the reinvestment of earnings, or the purchase of land, buildings or other real assets.

IMF dalam Balance of Payments Manual (1980), investasi asing (foreign direct investment) diartikan, "Investment that is made to acquire a lasting interest in an enterprise operating in an economy other than that of an investor, the investor's purpose being to have an effective choice in the management of the enterprise". ${ }^{11}$ Kemudian dalam draft text the Multilateral Agreement on Investment, investasi asing didefinisikan sebagai "every kind of asset owned or controlled, directly or indirectly, by an investor". ${ }^{12}$

Definisi investasi secara luas dalam Pasal 1 ayat (6) Energy Charter Treaty (ECT) ${ }^{13}$ meliputi "every kind of asset" yang dimiliki atau dikontrol secara lagsung atau tidak langsung oleh investor dan termasuk: (1) tangible and intangible, and movable and immovable, property, and any property rights such as leases, mortgages, liens, and pledges; (2) a company or business enterprise, or shares, stock, or other forms of equity participation in a company or business enterprise, and bonds and other debt of a company or business enterprise; (3) claims to money and claims to performance pursuant to contract having an economic value and associated

\footnotetext{
Terry Hutchinson, 2002, Researching and Writing in Law, Law Book Co., Melbourne, hlm. 9.

Peter Mahmud Marzuki, 2005, Penelitian Hukum, Kencana, Jakarta, hlm. 18-28.

Bandingkan dengan konsep "the words and phrases approach" dari Terry Hutchinson, Op.cit., hlm. 36.

Peter Mahmud Marzuki, Loc.cit.

M. Sornarajah, 1994,The International Law on Foreign Investment, Cambridge University Press, Cambridge, hlm. 4.

Robert Pritchard, 1996, The Contemporary Challenges of Economic Development, Kluwer Law International, London, hlm. 3.

Alfred Escher, 1999, Legal Aspect of Foreign Investment, Kluwer Law International, the Hague, Boston, hlm. 20.

Multilateral Agreement on Investment, 1995, Organization for Economic and Development (OECD), Article II. Sec. 2.

Negosiasai teks ECT berlangsung dari 1991 - 1994 dalam konfrensi European Energy Charter yang dihadiri oleh 50 negara dan European Communites (EC), yang ditutup di Lisbon pada 17 Desember 1994 dengan ditandatanganinya Final Act dan dibukanya penandatanganan bagi ECT.
} 
with an investment; (4) intellectual property; (5) returns; (6) any right conferred by law or contract or by virtue of any licences and permits granted pursuant to law to undertake any Economic Activity in the Energy Sector.

Undang-Undang Penanaman Modal Indonesia memisahkan pengertian investasi (penanaman modal) dan aset (modal), investasi berkaitan dengan kegiatan, subyek, wilayah sedangkan modal berkaitan dengan instrumen. Kedua pengertian ini masih dibedakan lagi dengan kategori asing dan dalam negeri, ini dapat diperhatikan dalam Pasal 1 Undang-Undang Nomor 25 Tahun 2007 tentang Penanaman Moda ${ }^{14}$ atau dalam Undang-Undang Penanaman Modal sebelumnya yang telah dicabut dan dinyatakan tidak berlaku, yaitu Undang-undang Nomor 1 Tahun 1967 tentang Penanaman Modal Asing dan Undang-Undang Nomor 6 Tahun 1968 tentang Penanaman Modal dalam Negeri. United Nations mendefinisikan investasi asing adalah "An investment involving a long term relationship and reflecting a lasting interest of a resident entity (individual or business) in one economy (direct investor) in an entity resident in an economy other than that of the investor (host country)". ${ }^{15}$ Secara umum investasi asing diartikan sebagai investasi oleh bukan warga negara melalui pembentukan atau akuisisi aset modal di host country. Investasi asing secara tidak langsung menunjukkan kepemilikan aset modal yang cukup banyak untuk memiliki kontrol sebagian atau sepenuhnya terhadap perusahaan dan adanya kehadiran fisik dari perusahaan asing atau para individu. Dalam kondisi ini, investasi asing termasuk tidak saja transfer modal, tetapi juga seluruh modal, teknologi, teknik produksi, pengetahuan manajemen, pemasaran dan bisnis. $^{16}$

Konsep divestasi berasal dari kata divest yang bermakna sama dengan devest dan kedua kata ini sering dipertukarkan, yang berarti: 17 "to deprive; to take away; to withdraw. Usually spoken of an authority, power, property, or title; as the estate is devest. Devest is opposite to invest. As to invest signifies to deliver the possession of anything to an other, so to devest signifies to take it away. Jacob. It is sometimes written "divest"but "devest" has the support of the best authority. Burrill".

Melihat pengertian di atas, divestasi diartikan sebagai tindakan mencabut, atau menarik, hal ini berbeda dengan investasi, kalau investasi adalah usaha mengalihkan kepemilikan ke pihak lain, sedangkan divestasi adalah usaha menariknya. Dengan demikian dapat disimpulkan bahwa divestasi adalah pengalihan sebagian dari aset kepada pihak lain, dan hal ini dapat diamati pada proses divestasi yang dilakukan PT NNT, bahwa berdasarkan Pasal 24 ayat (4) Kontrak Karya, PT NNT mempunyai kewajiban pengalihan sebagian dari saham-saham yang dimiliki peserta asing kepada peserta Indonesia dengan penawaran pertama kepada Pemerintah.

\section{Kepemilikan Saham pada PT Newmont Nusa Tenggara (PT NNT)}

PT Newmont Nusa Tenggara (PT NNT) adalah perusahaan yang bergerak dalam bidang tambang dengan produk utama tembaga (copper). Pemegang saham pada awalnya adalah Nusa Tenggara Mining Corporation dan Sumitomo Corporation yang memiliki saham mayoritas dari PT NNT (80\%), dan yang mewakili perusahaan lokal yaitu PT Pukuafu Indah Indonesia yang memegang 20\% dari keseluruhan saham.

Pada tahun 1986 PT NNT melakukan perjanjian dengan Pemerintah RI, dan memulai operasional tambangnya pada tahun 2000. Luas Kontrak Karya yang didapatkan adalah sebesar 1.127.134 hektar, dengan nilai investasi awal sebesar US\$ 1,9 miliar. Kontrak karya diberikan dengan

\footnotetext{
Undang-Undang Republik Indonesia Nomor 25 Tahun 2007 tentang Penanaman Modal (Lembaran Negara Republik Indonesia Tahun 2007 Nomor 7, Tambahan Lembaran Negara Republik Indonesia Nomor 4724).

Pham Hoang Mai, 2004, FDI and Development in Vietnam, Policy Implications, Institute of Southeast Asian Studies, Singapore, hlm. 4.

M. Gillis, et al., 1992, Economic of Development, W.W. Norton and Co., New York, hlm. 4-5.

Bryan A. Garner, 2009, Black's Law Dictionary, West Group, Minnesota.
} 
perjanjian kewajiban divestasi saham asing mulai tahun 2006 hingga akhir 2010. Dengan perhitungan $20 \%$ saham sudah dimiliki swasta nasional, sehingga sisa saham yang harus didivestasikan sebesar 31\% hingga akhir 2010.

Divestasi saham PT NNT pada tahun 2006 telah menawarkan 3\% kepada pemerintah. Namun pemerintah pusat melalui Menteri Keuangan telah menolak untuk membeli saham yang kurang lebih bernilai US\$ 109 juta tersebut dengan alasan tidak adanya anggaran. Kemudian pada tanggal 13 Februari 2007 PT NNT menawarkan divestasi saham kepada tiga pemerintah daerah di NTB, yaitu Pemerintah Provinsi NTB, Pemerintah Daerah Kabupaten Sumbawa Barat (KSB), Pemerintah Daerah Kabupaten Sumbawa. Saat itu Pemerintah Daerah KSB menunjukkan ketertarikan untuk membeli saham namun meminta tambahan waktu atas tawaran tersebut, dengan alasan untuk melakukan due diligence (uji tuntas) atas kinerja operasional PT NNT, namun permohonan tersebut ditolak oleh Pemerintah Provinsi NTB walaupun pada saat itu juga menunjukkan ketertarikan untuk membeli saham tersebut.

Kesepakatan tiga pemerintah daerah tidak juga tercapai hingga melampaui batas akhir pembelian saham pada tanggal 23 Agustus 2007. Sehingga pembelian saham sebesar $3 \%$ dari PT NNT batal dilakukan. Di tahun 2007 PT NNT kembali menawarkan divestasi saham kepada pemerintah sebesar 7\% dengan nilai nominal mencapai US\$ 282 juta. Namun penawaran tahap kedua tersebut juga tidak ditanggapi oleh pemerintah mengenai pembelian saham, sehingga rencana divestasi kembali tertunda.

Setelah dua kali penawaran pembelian saham gagal dilakukan, pada 11 Februari 2008 pemerintah menganggap bahwa Newmont telah lalai karena tidak juga menjual saham sesuai dengan kontrak karya. Menjawab pernyataan pemerintah tersebut, pada 26 Februari 2008 PT NNT mengajukan penundaan divestasi. Namun pengajuan tersebut ditolak oleh pemerintah, dan pada 3 Maret 2008 pemerintah mengajukan gugatan atas sengketa divestasi Newmont ke Arbitrase Internasional karena hingga tanggal tersebut PT NNT belum juga melaksanakan divestasi saham sesuai kontrak karya yang telah disepakati bersama.

Pada tanggal 31 Maret 2009 Majelis Arbitrase mengumumkan secara resmi putusan yang memenangkan Pemerintah Indonesia gugatan atas kasus Divestasi PT Newmont Nusa Tenggara (PT NNT) di Arbitrase Internasional, dengan keputusan "PT Newmont Nusa Tenggara wajib mendivestasikan $17 \%$ sahamnya dalam waktu 180 hari. Jika dalam waktu 180 hari sejak putusan arbitrase dikeluarkan Newmont tidak juga mendivestasikan sahamnya, maka Pemerintah Indonesia berhak mencabut Kontrak Karyanya". Sesuai prosedur arbitrase menurut United Nation Commision on International Trade Law (UNCITRAL), saham yang didivestasikan harus bebas dari gadai (clean and clear), dan sumber dana pembelian saham tersebut bukan menjadi urusan PT NNT dan PT NNT dinyatakan bersalah oleh Majelis Arbitrase karena telah melakukan pelanggaran perjanjian. Sehingga PT NNT diperintahkan untuk melaksanakan ketentuan Pasal 24 ayat (3) Kontrak Karya.

Sebagai tambahan, pada tahun 1996 PT NNT menggadaikan seluruh saham asingnya yang dimiliki Sumitomo dan Newmont Mining Corporation sebanyak $80 \%$ kepada Senior Lender yang terdiri dari Export Import Bank of Japan, US Export Import Bank, dan Kreditstanlt fur Wiederaufbau (KFW) Jerman, sebesar US\$ 1 miliar untuk mengembangkan proyek. Akan tetapi, PT NNT telah melunasi sebagian, sehingga sisa US\$ 300 juta.

Dengan adanya keputusan tersebut, pihak NNT menyatakan tetap berkomitmen untuk tetap melanjutkan divestasi saham seperti yang telah disepakati dalam kontrak karya. Namun, perlu dibahas lebih lanjut langkah-langkah kedepan dengan pemerintah guna melaksanakan Putusan Panel Arbitrase. Sampai dengan akhir April 2009, Kementerian Negara Badan Usaha Milik Negara (BUMN) masih mengevaluasi dua alternatif 
pembelian saham Newmont. Pertama, pemerintah dapat mengambil alih secara langsung. Kedua, melalui BUMN di sektor pertambangan.

Evaluasi tersebut dengan mempertimbangkan tiga aspek yang menjadi konsentrasi utama pemerintah pusat. Pertama, nilai strategis dari komoditas pertambangan itu sendiri. Kedua, pertimbangan keuntungan bagi keuangan negara dan perekonomian secara keseluruhan apabila memutuskan membeli saham tersebut. Ketiga, aspek keberlangsungan dari aktivitas eksploitasi dan penjualan hasil komoditas tambang batu hijau itu sendiri bagi kas negara.

Divestasi saham yang dilakukan hingga tahun 2009 dengan total divestasi 24\% adalah sebesar US\$ 1,165 miliar atau setara dengan Rp 12,41 triliun (dengan asumsi US\$1 setara dengan Rp10.655). Sehingga apabila dihitung secara matematis untuk 100 persen saham PT NNT adalah sebesar US\$ 4,854 miliar atau setara dengan Rp 51,72 triliun. Sesuai Pasal 24 ayat (3) Kontrak Karya, jika pemerintah tidak menerima penawaran saham, kesempatan berikutnya jatuh pada Warga Negara Indonesia atau Perusahaan Indonesia yang dikendalikan warga Indonesia. Namun dengan berlakunya otonomi daerah, tidak hanya Pemerintah Pusat yang berhak membeli saham asing erusahaan tambang, Pemerintah Daerah juga memiliki kesempatan yang sama.

Untuk divestasi tahun 2010 ternyata sampai saat ini belum dilakukan, hal ini disebabkan karena keinginan Pemerintah Pusat untuk membeli saham tahun 2010, sementara itu juga Kabupaten Sumbawa Barat berkeinginan memiliki saham tersebut, padahal antara Provinsi NTB, Kabupaten Sumbawa Barat dan Kabupaten Sumbawa memiliki perjanjian kerjasama untuk mengusahakan pembelian saham bersama, hal inilah menjadi kendala lancarnya proses divestasi pada tahun 2010 , tentang hal ini akan dibahas pada uraian selanjutnya.

\section{Kebijakan Daerah dalam Divestasi}

Divestasi pada dasarnya adalah merupakan bagian permasalahan yang berada dalam konteks investasi yang secara sistematik menyangkut dengan banyak peraturan, dan pembicaraan mengenai investasi mencakup beberapa aspek yang, yaitu permasalahan sosial, ekonomi, politik dan keamanan. Selain itu, juga aspek pengaturan yang terkait karena bidang aktivitas yang dilakukan seperti pengaturan tentang tanah, hutan, lingkungan, konservasi, perizinan (administrasi), pajak, kontrak, perusahaan, pemerintahan daerah, bidang usaha, dan pengaturan investasinya sendiri.

Terkait dengan divestasi saham, maka daerah menggunakan aset daerah sebagai modal untuk melakukan divestasi, pada prinsipnya bahwa aset daerah adalah milik masyarakat daerah, sehingga segala bentuk pemanfaatan dan pengalihannya haruslah didasarkan pada persetujuan masyarakat (dewan), karena dia bukan milik pribadi atau pejabat yang ada di daerah. Penjabaran dari prinsip ini dapat dilihat dalam kebijakan yang terdapat pada beberapa peraturan perundang-undangan seperti Pasal 195 Undang-Undang Nomor 32 Tahun 2004 tentang Pemerintahan Daerah ${ }^{18}$ menyebutkan bahwa kerja sama yang membebani masyarakat dan daerah harus mendapatkan persetujuan DPRD. Pasal 24 Undang-Undang Nomor 17 Tahun 2003 tentang Keuangan Negara $^{19}$ mengatur bahwa penyertaan modal terlebih dahulu ditetapkan dalam Anggaran Pendapatan dan Belanja Daerah (APBD). Lebih jelas lagi, dalam Pasal 41 Undang-Undang Nomor 1 Tahun 2004 tentang Perbendaharaan Negara menyebutkan penyertaan modal pemerintah daerah pada perusahaan negara/daerah/swasta ditetapkan dengan peraturan daerah. Berdasarkan uraian di atas dapat disimpulkan bahwa kegiatan yang membebani masyarakat dan daerah seperti

18 Undang-Undang Nomor 32 Tahun 2004 tentang Pemerintahan Daerah (Lembaran Negara Republik Indonesia Tahun 2004 Nomor 125, Tambahan Lembaran Negara Republik Indonesia Nomor 4437) sebagaimana telah diubah terakhir dengan Undang-Undang Nomor 12 Tahun 2008 tentang Perubahan Kedua Atas Undang-Undang Nomor 32 Tahun 2004 tentang Pemerintahan Daerah (Lembaran Daerah Republik Indonesia Nomor 59, Tambahan Lembaran Negara Republik Indonesia Nomor 4844).

19 Undang-Undang Republik Indonesia Nomor 17 Tahun 2003 tentang Keuangan Negara (Lembaran Negara Republik Indonesia Tahun 2003 Nomor 47, Tambahan Lembaran Negara Republik Indonesia Nomor 4286). 
dalam bentuk penyertaan modal harus mendapatkan persetujuan dewan dan ditetapkan dengan peraturan daerah.

Kemudian dalam Pasal 75 Peraturan Pemerintah Nomor 58 Tahun 2005 tentang Pengelolaan Keuangan Daerah ${ }^{20}$, disebutkan Penyertaan modal pemerintah daerah dapat dilaksanakan apabila jumlah yang akan disertakan dalam tahun anggaran berkenaan telah ditetapkan dalam peraturan daerah tentang penyertaan modal daerah berkenaan. Selain itu, Pasal 9 Peraturan Pemerintah Nomor 50 Tahun 2007 tentang Kerja Sama Daerah" ${ }^{21}$ menyebutkan, "Rencana Kerja Sama Daerah yang membebani daerah dan masyarakat harus mendapat persetujuan dari Dewan Perwakilan Rakyat Daerah dengan ketentuan apabila biaya kerja sama belum teranggarkan dalam Anggaran Pendapatan dan Belanja Daerah tahun anggaran berjalan dan/atau menggunakan dan/atau memanfaatkan aset daerah".

Aturan di atas dapat diartikan bahwa segala pengeluaran daerah termasuk dalam hal ini adalah untuk kepentingan divestasi harus dianggarkan dalam APBD dan terkait dengan penyertaan modal dilakukan berdasarkan surat perintah membayar yang diterbitkan oleh pejabat pengelola keuangan daerah, sehingga jika ada anggaran yang dikeluarkan tanpa adanya persetujuan terlebih dahulu dan ditetapkan dengan peraturan daerah, maka hal tersebut dapat digolongkan pelanggaran, karena aset daerah merupakan milik masyarakat (bukan perorangan). Dengan demikian bahwa terkait dengan penggunaan aset apakah berbentuk uang atau barang yang digunakan oleh badan usaha milik daerah harus dianggarkan, disetujui dan ditetapkan dengan peraturan daerah.

Dalam melakukan divestasi ketiga daerah telah membentuk sebuah badan usaha yang merupakan badan usaha milik daerah. Badan
Usaha di daerah dapat berupa Perusahaan Daerah (PD) atau Perseroan Terbatas (PT). Pengaturan pendirian PT dalam Undang-Undang Nomor 40 Tahun 2007 tentang Perseroan Terbatas ${ }^{22}$ cukup sederhana, artinya bahwa PT dapat didirikan dengan adanya minimal dua orang yang berjanji, tertuang dalam akta notaris, dengan modal dasar yang seluruhnya terbagi dalam saham, didaftar di pengadilan, kemudian perseroan akan memperoleh status badan hukum pada tanggal diterbitkannya Keputusan Menteri mengenai pengesahan badan hukum Perseroan, dan terakhir diumumkan dalam Berita Negara.

Tetapi terkait dengan PT yang berstatus BUMD, maka tidak bisa hanya berdasar pada Undang-Undang Nomor 40 Tahun 2007, walaupun dalam Peraturan Menteri Dalam Negeri Nomor 3 Tahun 1998 tentang BUMD ditetapkan bahwa Badan Usaha Milik Daerah yang bentuk hukumnya berupa Perseroan Terbatas tunduk pada Undang-Undang Nomor 1 Tahun 1995 tentang Perseroan Terbatas dan peraturan pelaksanaannya. Hal ini disebabkan karena Undang-Undang Nomor 1 Tahun 1995 sudah diganti, serta terdapat pengaturan dalam peraturan yang lebih tinggi yaitu Undang-Undang Nomor 32 Tahun 2004 tentang Pemerintahan Daerah.

Dalam Pasal 177 Undang-Undang Nomor 32 Tahun 2004 diatur bahwa Pemerintah daerah dapat memiliki BUMD yang pembentukan, penggabungan, pelepasan kepemilikan, dan/atau pembubarannya ditetapkan dengan Peraturan Daerah yang berpedoman pada peraturan perundang-undangan. Norma ini bersifat alternatif dan kumulatif. Seperti disebutkan di atas bahwa BUMD dapat berbentuk PD atau PT, sehingga dapat diartikan bahwa PD atau PT yang berstatus BUMD dalam hal pembentukan, penggabungan, pelepasan kepemilikan, dan/atau pembubarannya ditetapkan dengan Peraturan Daerah. Peraturan Daerah ini

20 Peraturan Pemerintah Republik Indonesia Nomor 58 Tahun 2005 tentang Pengelolaan Keuangan Daerah (Lembaran Negara Republik Indonesia Tahun 2005 Nomor 140, Tambahan Lembaran Negara Republik Indonesia Nomor 4578).

21 Peraturan Pemerintah Republik Indonesia Nomor 50 Tahun 2007 tentang Tata Cara Pelaksanaan Kerja Sama Daerah (Lembaran Negara Republik Indonesia Tahun 2007 Nomor 112, Tambahan Lembaran Negara Republik Indonesia Nomor 4761).

22 Undang-Undang Republik Indonesia Nomor 40 Tahun 2007 tentang Perseroan Terbatas (Lembaran Negara Republik Indonesia Tahun 2007 Nomor 106, Tambahan Lembaran Negara Republik Indonesia Nomor 4756). 
adalah validitas dari sebuah badan usaha milik daerah, sebagai perbandingan kalau dalam Pasal 4 Undang-Undang Nomor 5 Tahun 1962 tentang PD disebutkan bahwa PD didirikan dengan Peraturan Daerah, dan kedudukannya sebagai badan hukum diperoleh dengan berlakunya Peraturan Daerah tersebut. Untuk mengakuisisi saham PT NNT yang harus didivestasikan sesuai perjanjian kontrak karya (KK), maka tiga Pemerintah Daerah (Pemerintah Daerah Provinsi Nusa Tenggara Barat (NTB), Pemkab. Sumbawa Barat (KSB) dan Pemkab. Sumbawa) telah membentuk sebuah konsorsium dengan payung PT Daerah Maju Bersaing (PT DMB).

\section{Sikap Pemerintah Pusat terhadap Sisa Saham 7\% Tahun 2010}

Dalam Pasal 129 Undang-Undang Nomor 4 Tahun 2009 tentang Pertambangan Mineral dan Batubara $^{23}$ (Minerba), bahwa negara mendapat $10 \%$ dari keuntungan bersih yang wajib dibayar perusahaan, dengan pembagian: 4\% Pemerintah, 6\% Pemerintah Daerah, yang dibagi: 1\% provinsi, $2,5 \%$ daerah penghasil, 2,5\% kabupaten/kota lainnya dalam provinsi.

Komposisi di atas sering menimbulkan perbedaan persepsi antara semua pihak-pihak yang terkait karena terlihat tidak adil, karena pemerintah pusat dinilai mendapat hampir 50\% dengan sumbangan peranan yang sangat kecil. Pemerintah daerah merasa harus mendapatkan proporsi yang lebih tinggi karena alasan akan menjadi penanggung segala dampak negatif kelak jika perusahaan sudah selesai beroperasi. Selain itu, Pemerintah pusat bersama DPR dinilai sangat lemah dalam membentuk Undang-Undang Minerba, karena hanya mampu mendapat $10 \%$ dari $100 \%$ pembagian hasil bersih produksi.

Saat ini berbagai gejolak sering bermunculan yang menuntut bahwa daerah-daerah penghasil tambang harus mendapat pembagian yang lebih proporsional. Selain itu, tuntutan juga mengarah kepada Undang-Undang Minerba yang perlu untuk dilakukan review sesuai dengan dinamika yang ada di daerah karena Undang-Undang Minerba yang ada sekarang dinilai akan memposisikan daerahdaerah hanya sebagai penonton dan pihak yang dirugikan dalam kegiatan pertambangan yang ada di daerahnya.

Salah satu permasalahan dalam bidang pertambangan saat ini adalah tentang divestasi saham PT NNT tahun 2010, bahwa berdasarkan Pasal 24 ayat (4) Kontrak Karya antara Pemerintah dengan PT NNT, divestasi berakhir pada tahun 2010 dengan komposisi pemilikan 51\% Peserta Indonesia. Waktu penawaran saham perusahaan kepada Peserta Indonesia tersebut dapat diperpanjang dengan persetujuan Pemerintah. Proses divestasi ini ternyata tidak sederhana seperti apa yang tertuang dalam kontrak karya, karena walaupun pemilikan saham tersebut merupakan hak yang dapat dimiliki tapi ternyata dibutuhkan dana yang sangat besar dari daerah untuk mendapatkannya.

Terkait dengan keinginan Pemerintah Pusat terhadap saham $7 \%$, telah menimbulkan perdebatan yang sangat sengit dan berkepanjangan. Pemerintah Daerah menilai bahwa berdasarkan Pasal 24 ayat (3) tidak terdapat hierarki dan prioritas antara Pemerintah Pusat dan Pemerintah Daerah dalam proses mendapatkan saham divestasi. Yang ada adalah antara Pemerintah dengan WNI atau perusahaan Indonesia yang dikendalikan oleh WNI. Pasal 24 ayat (3) mengatur tentang urutan dalam penawaran saham, yaitu Pemerintah dan WNI atau Perusahaan Indonesia yang dikendalikan oleh WNI.

Tidak adanya hierarki atau prioritas antara Pemerintah Pusat dengan Pemerintah Daerah dalam proses mendapatkan saham divestasi, ditafsirkan bahwa dalam penawaran saham Pemerintah Pusat dan Pemerintah Daerah menjadi pihak dalam penawaran saham. Dengan demikian terkait dengan pemilikan saham divestasi sebesar 7\% pada tahun 2010 ini perlu ada komunikasi antara Pemerintah

23 Undang-Undang Republik Indonesia Nomor 4 Tahun 2009 tentang Pertambangan Mineral dan Batubara (Lembaran Negara Republik Indonesia Tahun 2009 Nomor 4, Tambahan Lembaran Negara Republik Indonesia Nomor 4959). 
dengan Pemda, dan tidak tepat jika Pemerintah Pusat menunjukkan dominasinya terhadap daerah. Hal ini berlainan dengan kasus divestasi saham 10\% untuk tahun 2006 dan 2007 senilai US\$ 391 juta (Rp4,1 triliun lebih) yang memang mutlak milik daerah berdasarkan Keputusan Arbitrase UNCITRAL antara Pemerintah RI melawan PT NNT pada tanggal 31 Maret 2009, dimana Indonesia diwakili oleh arbitrator M. Sornarajah yang juga merupakan seorang pakar hukum investasi ternama.

Permasalahan terkait dengan divestasi saham 7\% PT NNT untuk tahun 2010 berawal dari keinginan Pemerintah Pusat untuk membeli saham tersebut. Hal ini terlihat dari Surat Menteri ESDM menyampaikan penawaran saham divestasi PT NNT pada Tanggal 25 November 2010 melalui surat Nomor 7349/80/MEM.B/2010 kepada Menkeu. Kemudian DPR RI pada Tahun 2011 berdasarkan Surat Nomor PW.01/5188/DPR RI/2011 tanggal 21 Juni 2011 telah memohon kepada BPK untuk melakukan audit dengan tujuan tertentu terhadap proses pembelian 7\% saham divestasi PT NNT. Seperti yang tercantum dalam Pasal 24 ayat (3) dan ayat (4) Kontrak Karya pada tanggal 2 Desember 1986 terdapat kewajiban PT NNT untuk melakukan divestasi: Pertama, PT NNT harus menjamin bahwa saham-saham yang dimiliki oleh Penanam Modal Asing akan ditawarkan untuk dijual atau diterbitkan, pertama-tama kepada Pemerintah, dan kedua (jika Pemerintah tidak menerima (menyetujui) penawaran itu, dalam waktu 30 (tiga puluh) hari sejak tanggal penawaran), kepada Warga Negara Indonesia atau Perusahaan Indonesia yang dikendalikan oleh Warga Negara Indonesia. Penawaran kepada Pemerintah atau Warga Negara Indonesia akan disebut suatu penawaran kepada Peserta Indonesia. Kedua, jumlah saham yang wajib ditawarkan dan dibeli oleh Peserta Indonesia setelah tidak kurang dari 51 persen dari saham yang diterbitkan oleh perusahaan.

Dalam pasal tersebut juga diatur bahwa penawaran tersebut dimulai pada tahun kelima produksi dengan besar sekurang-kurangnya: 15\% (tahun ke-5), 23\% (tahun ke-6), 30\% (tahun ke-7), 37\% (tahun ke-8), 44\% (tahun ke-9), dan 51\%(tahun ke-10). Berdasarkan surat DPR Nomor PW.01/5188/DPR RI/2011 tersebut, BPK mengeluarkan Laporan Hasil Pemeriksaan (LHP) Nomor 45/HP/XV/10/2011 tanggal 14 Oktober 2011 pada pokoknya berkesimpulan berdasarkan ketentuan Pasal 24 Undang-Undang Nomor 17 Tahun 2003 tentang Keuangan Negara dan Pasal 41 Undang-Undang Nomor 1 Tahun 2004 tentang Perbendaharaan Negara menyatakan bahwa keputusan Pemerintah melakukan investasi jangka panjang melalui PIP dalam bentuk penyertaan modal pada perusahaan swasta, harus ditetapkan dengan peraturan pemerintah setelah mendapat persetujuan DPR.

LHP BPK didasarkan pada peraturan perundang-undangan yang berlaku, di samping itu jika mencermati kebijakan yang dikeluarkan oleh Menteri Keuangan, bahwa pembelian saham tersebut tidak sesuai dengan kebijakan yang telah dikeluarkan. Terkait dengan investasi dalam bentuk saham Menteri Keuangan pada tanggal 20 November 2008 menetapkan PMK Nomor 181/ PMK.05/2008, di dalam Pasal 6 ayat (1) disebutkan bahwa "Investasi dengan cara pembelian saham dilakukan atas saham yang diterbitkan perusahaan terbuka". Artinya berdasarkan PMK Nomor 181/ PMK.05/2008 pemerintah hanya boleh membeli saham yang diterbitkan oleh perusahaan terbuka, sementara PT NNT bukanlah perusahaan terbuka yang melakukan penawaran saham di pasar modal. Tapi ternyata pada tanggal 16 Desember 2010 Menkeu menyampaikan bahwa Pemerintah RI akan melaksanakan hak untuk membeli saham divestasi PT NNT (perusahaan tertutup) tahun 2010 melalui surat Nomor S-671/MK.06/2010 kepada Menteri ESDM. Jika dicermati Surat Menkeu ini ternyata telah menyalahi ketentuan PMK Nomor 181/PMK.05/2008 karena PT NNT merupakan perusahaan tertutup.

Menindaklanjuti hak untuk membeli saham PT NNT Menkeu menetapkan KMK Nomor 43/ KMK.06/2011, yang pada pokoknya menetapkan PIP sebagai pembeli $7 \%$ saham divestasi PT 
NNT (perusahaan tertutup) tahun 2010. KMK ini cacat hukum karena ditetapkan pada saat berlakunya PMK Nomor 181/PMK.05/2008 yang hanya memperbolehkan pembelian saham yang diterbitkan perusahaan terbuka, sedangkan PT NNT merupakan perusahaan tertutup. Sebagai solusi terhadap permasalahan tersebut kemudian Menkeu mengubah PMK Nomor 181/PMK.05/2008 menjadi PMK Nomor 44/PMK.05/2011, dengan perubahan klausul dalam Pasal 6 ayat (1) sebagai berikut: "Investasi dengan cara pembelian saham dilakukan atas saham yang diterbitkan oleh perusahaan". Sesuai PMK Nomor 181/PMK.05/2008, Pemerintah hanya bisa melakukan investasi pada perusahaan terbuka, sedangkan PMK Nomor 44/PMK.05/2011 tanggal 9 Maret 2011, Pemerintah bisa melakukan investasi baik pada perusahaan terbuka maupun tertutup". Akhirnya, pada tanggal 6 Mei 2011 Kepala PIP untuk dan atas nama Pemerintah RI dan Nusa Tenggara Partnership BV (NTP BV) melakukan penandatanganan Perjanjian Jual Beli Saham Divestasi 2010 senilai US\$ 246.80 juta. Namun berdasarkan kajian berdasarkan peraturan kebijakan yang telah dikeluarkan oleh Menkeu bahwa ternyata Perjanjian Jual Beli Saham divestasi tahun 2010 cacat hukum karena didasarkan pada KMK Nomor 43/KMK.06/2011 yang juga cacat hukum karena bertentangan dengan PMK Nomor 181/PMK.05/2008 yang hanya memperbolehkan pembelian saham yang diterbitkan perusahaan terbuka, sedangkan PT NNT merupakan perusahaan tertutup.

\section{Kedudukan Pusat Investasi Pemerintah} (PIP) dan Sengketa antar Kewenangan

\section{Lembaga Negara}

Dalam Pasal 7 Undang-Undang Nomor 15 Tahun 2004 Tentang Pemeriksaan Pengelolaan dan Tanggung jawab Keuangan Negara ${ }^{24}$, disebutkan bahwa: Pertama, dalam merencanakan tugas pemeriksaan, BPK memperhatikan permintaan, saran, dan pendapat lembaga perwakilan. Kedua yakni dalam rangka membahas permintaan, saran, dan pendapat sebagaimana dimaksud pada ayat (1), BPK atau lembaga perwakilan mengadakan pertemuan konsultasi.

Kemudian dalam Undang-Undang Nomor 15 Tahun 2006 Tentang BPK ${ }^{25}$ Pasal 6 ayat (1) dinyatakan BPK bertugas memeriksa pengelolaan dan tanggung jawab keuangan negara yang dilakukan oleh Pemerintah Pusat, Pemerintah Daerah, Lembaga Negara lainnya, Bank Indonesia, Badan Usaha Milik Negara, Badan Layanan Umum, Badan Usaha Milik Daerah, dan lembaga atau badan lain yang mengelola keuangan negara. Dari ketentuan Undang-Undang Nomor 15 Tahun 2004 dan Undang-Undang Nomor 15 Tahun 2006, bahwa BPK memiliki kewenangan untuk memeriksa pengelolaan dan tanggung jawab keuangan negara yang lingkupnya sangat luas yaitu mencakup pemerintah dan lembaga-lembaga negara, termasuk dalam hal ini adalah pemeriksaan terhadap Pusat Investasi Pemerintah (PIP). PIP adalah lembaga yang didirikan sebagai pelaksanaan kesepakatan Pemerintah dan Panitia Anggaran DPR dalam Rapat Kerja tanggal 12 Juli sampai dengan 7 September 2006 dengan tujuan untuk mendukung percepatan pembangunan infrastruktur. PIP ditetapkan sebagai Badan Layanan Umum pada Kementerian Keuangan berdasarkan KMK Nomor 1005/KMK.05/2006 yang diubah terakhir dengan KMK Nomor 91/KMK.05/2009 tanggal 27 Maret 2009.

Dalam Pasal 1 ayat (2) PMK 52/PMK.01/2007 tentang Organisasi dan Tata Kerja PIP, menyatakan PIP merupakan instansi pemerintah yang berperan sebagai operator investasi pemerintah yang menerapkan pola pengeluaran keuangan Badan Layanan Umum (BLU). Secara organisasi, PIP berada di bawah dan bertanggung jawab kepada Menteri Keuangan. Berdasarkan KMK Nomor

24 Undang-Undang Republik Indonesia Nomor 15 Tahun 2004 tentang Pemeriksaan, Pengelolaan, dan Tanggung Jawab Keuangan Negara (Lembaran Negara Republik Indonesia Tahun 2004 Nomor 66, Tambahan Lembaran Negara Republik Indonesia Nomor 4400).

25 Undang-Undang Republik Indonesia Nomor 15 Tahun 2004 tentang Pemeriksaan, Pengelolaan, dan Tanggung Jawab Keuangan Negara (Lembaran Negara Republik Indonesia Tahun 2004 Nomor 66, Tambahan Lembaran Negara Republik Indonesia Nomor 4400). 
1005/KMK.05/2006 yang diubah terakhir dengan KMK Nomor 91/KMK.05/2009 tanggal 27 Maret 2009 dan PMK 52/PMK.01/2007, secara eksplisit dinyatakan bahwa PIP adalah Badan Layanan Umum (BLU).

Peraturan yang mengatur tentang BLU terdapat dalam Undang-Undang Nomor 1 Tahun 2004 tentang Perbendaharaan Negara. Pada Ketentuan Umum angka 23 disebutkan bahwa Badan Layanan Umum adalah instansi di lingkungan Pemerintah yang dibentuk untuk memberikan pelayanan kepada masyarakat berupa penyediaan barang dan/atau jasa yang dijual tanpa mengutamakan mencari keuntungan dan dalam melakukan kegiatannya didasarkan pada prinsip efisiensi dan produktivitas. Kemudian dalam Peraturan Pemerintah Nomor 23 Tahun 2005 tentang Pengelolaan Keuangan Badan Layanan Umum²6, Pasal 1 angka 1 disebutkan bahwa Badan Layanan Umum (yang selanjutnya disebut BLU) adalah Instansi di lingkungan Pemerintah yang dibentuk untuk memberikan pelayanan kepada masyarakat berupa penyediaan barang dan/atau jasa yang dijual tanpa mengutamakan mencari keuntungan dan dalam melakukan kegiatannya didasarkan pada prinsip efisiensi dan produktivitas".

Berdasarkan Undang-Undang Nomor 1 Tahun 2004, Peraturan Pemerintah Nomor 23 Tahun 2005, KMK Nomor 1005/KMK.05/2006 yang diubah terakhir dengan KMK Nomor 91/ KMK.05/2009 tanggal 27 Maret 2009 dan PMK 52/PMK.01/2007, dapat disimpulkan bahwa PIP adalah BLU, yang merupakan instansi di lingkungan Pemerintah yang dibentuk untuk memberikan pelayanan kepada masyarakat tanpa mengutamakan mencari keuntungan, sedangkan kekayaannya adalah kekayaan negara/daerah yang tidak dipisahkan, yang dikonsolidasikan dalam rencana kerja dan anggaran Kementerian Negara/ Lembaga/Pemerintah Daerah yang bersangkutan.

Dalam Pasal 24 Undang-Undang Nomor
17 Tahun 2003 diatur bahwa Pemerintah dapat memberikan pinjaman/hibah/penyertaan modal kepada dan menerima pinjaman/hibah dari perusahaan negara/daerah, yang ditetapkan dalam APBN/APBD. Pada ayat (7) disebutkan bahwa dalam keadaan tertentu, untuk penyelamatan perekonomian nasional, Pemerintah Pusat dapat memberikan pinjaman dan/atau melakukan penyertaan modal kepada perusahaan swasta setelah mendapat persetujuan DPR.

Di samping itu juga berdasarkan ketentuan Pasal 41 Undang-Undang Nomor 1 Tahun 2004 yang merupakan amanat Pasal 29 UndangUndang Nomor 17 Tahun 2003, PIP dalam hal ini Pemerintah dapat melakukan investasi jangka panjang untuk memperoleh manfaat ekonomi, sosial dan/atau manfaat lainnya. Investasi dilakukan dalam bentuk saham, surat utang, dan investasi langsung yang diatur dengan Peraturan Pemerintah, sedangkan penyertaan modal Pemerintah Pusat pada perusahaan negara/daerah/swasta ditetapkan dengan Peraturan Pemerintah, dan penyertaan modal pemerintah daerah pada perusahaan negara/ daerah/swasta ditetapkan dengan peraturan daerah.

Kedudukan PIP sebagai bagian dari Pemerintah inilah yang merupakan salah satu sebab sengketa antara Pemerintah dengan DPR dalam transaksi divestasi PT NNT. Karena PIP adalah bagian dari kementrian atau bukan merupakan lembaga yang terpisah dari Pemerintah sehingga penganggarannya dimasukkan dalam anggaran Kementerian yang direncanakan pada APBN yang mengharuskan adanya persetujuan DPR. Perdebatan tentang ini yang menjadi objek sengketa dalam kompetensi Mahkamah Konstitusi berdasarkan Undang-Undang Nomor 24 Tahun 2003 tentang Mahkamah Konstitusi, sehingga PIP sebagai BLU harus menuangkan secara rinci dan mendapat persetujuan DPR. Pembelian 7\% saham divestasi PT NNT belum terdapat di dalam APBN TA 2009, TA 2010, dan TA 2011. Oleh karena itu,

26 Undang-Undang Republik Indonesia Nomor 15 Tahun 2006 tentang Pemeriksaan, Pengelolaan, dan Tanggung Jawab Keuangan Negara (Lembaran Negara Republik Indonesia Tahun 2006 Nomor 85, Tambahan Lembaran Negara Republik Indonesia Nomor 4654). 
pendapat Pemerintah yang menyatakan bahwa telah mendapat persetujuan DPR RI melalui persetujuan terhadap RUU APBN adalah tidak tepat.

Terkait dengan divestasi $7 \%$ tahun 2010 sampai sekarang belum dilaksanakan, hal ini menimbulkan permasalahan baik secara ekonomi, hukum, sosial dan keamanan. Dari aspek ekonomi dengan terlambatnya atau tidak terealisasinya divestasi sebagaimana dalam kontrak karya maka akan menimbulkan kerugian bagi Negara dan khususnya Pemerintah Daerah, sebab Negara dan Pemerintah Daerah akan kehilangan keuntungan yang seharusnya diterima, dan hal tersebut akan berdampak terhadap pelaksanaan dan pengembangan program-program pemberdayaan masyarakat.

Secara hukum, dengan adanya keterlambatan ini akan memberi kesan bahwa investasi di Indonesia tidak memberikan kepastian hukum, karena dalam proses investasi sering timbul permasalahan karena tidak dilaksanakannya komitmen dan peraturan-peraturan yang telah dibentuk dalam bidang investasi. Dari aspek sosial dengan belum dilaksanakannya divestasi telah menimbulkan gejolak pada masyarakat, sebab masyarakat merasa berkepentingan dengan adanya perusahaan tambang tersebut sehingga menjadi sorotan banyak pihak, apalagi PT NNT adalah perusahaan besar yang termasuk perusahaan transnasional sehingga akan mudah diekspose ke media. Gejolak yang terjadi tidak saja antara masyarakat yang sifatnya horizontal, tapi juga antar Pemerintah Daerah yaitu terjadinya konflik antara Provinsi NTB dengan Kabupaten Sumbawa Barat dan Kabupaten Sumbawa. Konflik tersebut tidak saja antar Pemerintah Daerah tapi juga antara pemerintah daerah dengan Pemerintah Pusat, sebab keinginan Pemerintah Pusat mengambil saham 7\% tahun 2010 telah membuat pemerintah daerah bingung dengan motivasi dari Pemerintah Pusat, karena keinginan tersebut tidak tampak dari divestasi yang 24\% sebelumnya.

Namun saham 24\% yang dikatakan milik Pemerintah Daerah ternyata menyisakan beberapa permasalahan, diantaranya yaitu bahwa PT MDB yang merupakan konsorsium dari PT DMB dan PT MC telah memberitahukan kepada PT NNT bahwa $24 \%$ saham yang mereka miliki telah digadaikan kepada PT Credit Suisse Singapore, sehingga hasil dividen langsung dibayarkan kepada PT Credit Suisse Singapore. Saham tersebut diagunkan karena PT MDB telah meminjam kepada Credit Suisse Singapore sebesar US\$300 juta. Konsekuensinya, seluruh income yang dihasilkan MDB, termasuk dividen Newmont, digunakan untuk membayar kewajiban pinjaman dengan porsi tanggung jawab pemerintah daerah sebesar 25\%. Dengan 24\% saham, maka PT MDB akan memperoleh dividen US\$187.751.655,00 yang disetorkan kepada PT MDB di rekening Credit Suisse Singapore sebagai kreditor PT MDB.

Mengenai dana US\$72.000.000,- yang dikatakan Gubernur NTB telah diterima Pemda, sebenarnya US\$38.000.000,- adalah bantuan langsung PT NNT kepada Pemda NTB yang tidak terkait dengan dividen. Saat ini kepemilikan saham PT NNT adalah: PT Pukuafu Indah sebesar 17,8\%; PT Multi Daerah Bersaing sebesar 24\%; PT Indonesia Masbaga 2,2\%; dan pemegang saham asing sebesar 56\%. Persepsi awal masyarakat adalah PT DMB mendapat Golden Share sebesar $25 \%$ dari pembelian saham divestasi PT NNT. Namun pernyataan tersebut berbeda dengan pasal 7.1 a,b perjanjian kerjasama, dimana semua adalah utang. Untuk itu, sinkronisasi terkait hal tersebut sangat mendesak dilakukan.

Divestasi saham PT NNT tahun 2006 dan 2007 jika ditambah dengan saham 2008 dan 2009 telah mencapai 24\%. Namun, saham 24\% tersebut tidak semua dimiliki oleh Pemerintah Daerah. Hal ini disebabkan karena untuk pembelian saham, Pemerintah Daerah menggandeng MC anak perusahaan Bumi Resources dengan komposisi pembagian 75:25. Artinya, Pemerintah Daerah hanya memiliki $6 \%$ dan harus dibagi 3 (Provinsi NTB, Kabupaten Sumbawa Barat, dan Kabupaten Sumbawa) dengan porsi pembagian 4:4:2 (2,4 Provinsi NTB, 2,4 Kabupaten Sumbawa Barat dan 
1,2 Kabupaten Sumbawa). Konsekuensi logis dari kepemilikan saham yang sangat kecil ini adalah kontrol Pemda terhadap kebijakan yang ada di Perusahaan PT NNT akan sangat lemah. Kondisi ini diperparah oleh hubungan antara daerah yang tidak solid.

\section{Kesimpulan}

Dengan kepemilikan 75\% PT MC dan 25\% PT DMB pada $24 \%$ saham NNT, maka PT DMB memiliki sebanyak $6 \%$ saham yang dibagi kepada Provinsi (40\%), KSB (40\%), dan Sumbawa (20\%). Jadi masing-masing daerah memiliki saham adalah Provinsi NTB 2,4\%, KSB 2,4\%, dan Kabupaten Sumbawa $1,2 \%$. Dengan kepemilikan daerah yang hanya $6 \%$ dari $100 \%$ saham pada PT NNT sebenarnya sangat kecil dibandingkan dengan hak daerah untuk memiliki $24 \%$ saham yang ada pada PT NNT, karena ternyata saham yang $6 \%$ tersebut harus dibayar atau tidak gratis sebagaimana yang tertuang dalam perjanjian antara PT DMB dengan PT MC.

Sengketa antara Pemerintah dengan DPR berkaitan dengan divestasi 7\% saham PT NNT telah diputus oleh Mahkamah Konstitusi yang mengharuskan Pemerintah meminta persetujuan

kepada DPR dalam pembelian saham tersebut, artinya bahwa anggaran untuk pembelian saham harus dianggarkan pada APBN yang disetujui oleh DPR. Kepemilikan saham Pemerintah Daerah menjadi sangat penting karena dengan kepemilikan tersebut dapat memberikan peluang bagi daerah uantuk berperan serta dalam investasi yang dilakukan di daerahnya. Namun untuk investasi selanjutnya haruslah dipersiapkan dengan baik baik dari aspek kebijakan ataupun perjanjian yang akan dilalakukan, sehingga tidak menimbulkan kerugian seperti proses divestasi yang ada saat ini, sehingga untuk memperlancar divestasi saat ini dan rencana investasi ke depan, Pemerintah Daerah perlu melakukan komunikasi dengan Pemerintah Pusat dan meningkatkan konsolidasi antar daerah (Provinsi, KSB, Sumbawa, dan memperkuat kelembagaan PT DMB dan PT MDB.

Adapun untuk saat ini, hal yang urgen dilakukan oleh Pemerintah Daerah adalah melakukan legal audit terhadap dokumen-dokumen yang terdapat antara PT DMB dengan pihak ketiga, sehingga dapat mengetahui peta permasalahan yang ada dan memudahkan mencari solusi terhadap problem yang menimpa pemerintah daerah.

\section{DAFTAR PUSTAKA}

\section{A. Buku}

Escher, Alfred, 1999, Legal Aspect of Foreign Investment, Kluwer Law International, the Hague, Boston.

Gillis, M., et al., 1992, Economic of Development, W.W. Norton and Co., New York.

Hutchinson, Terry, 2002, Researching and Writing in Law, Law Book Co., Melbourne.

Garner, Bryan A., 2009, Black's Law Dictionary, West Group, Minnesota.

Mai, Pham Hoang, 2004, FDI and Development in Vietnam, Policy Implications, Institute of Southeast Asian Studies, Singapore.

Marzuki,Peter Mahmud 2005, Penelitian Hukum, Kencana, Jakarta.

Pritchard, Robert, 1996, The Contemporary
Challenges of Economic Development, Kluwer Law International, London.

Sornarajah, M., 1994, The International Law on foreign Investment, Cambridge University Press, Cambridge.

\section{B. Peraturan Perundang-Undangan}

Undang-Undang Republik Indonesia Nomor 17 Tahun 2003 tentang Keuangan Negara (Lembaran Negara Republik Indonesia Tahun 2003 Nomor 47, Tambahan Lembaran Negara Republik Indonesia Nomor 4286). Undang-Undang Republik Indonesia Nomor 1 Tahun 2004 tentang Perbendaharaan Negara (Lembaran Negara Republik Indonesia Tahun 2004 Nomor 5, Tambahan Lembaran Negara 
Republik Indonesia Nomor 4355).

Undang-Undang Nomor 32 Tahun 2004 tentang

Pemerintahan Daerah (Lembaran Negara

Republik Indonesia Tahun 2004 Nomor

125, Tambahan Lembaran Negara Republik

Indonesia Nomor 4437) sebagaimana telah

diubah terakhir dengan Undang-Undang

Nomor 12 Tahun 2008 tentang Perubahan

Kedua Atas Undang-Undang Nomor 32

Tahun 2004 tentang Pemerintahan Daerah

(Lembaran Daerah Republik Indonesia

Nomor 59, Tambahan Lembaran Negara

Republik Indonesia Nomor 4844).

Undang-Undang Republik Indonesia Nomor 25 tahun 2007 tentang Penanaman Modal (Lembaran Negara Republik Indonesia Tahun 2007 Nomor 7, Tambahan Lembaran Negara Republik Indonesia Nomor 4724).

Undang-Undang Republik Indonesia Nomor 40

Tahun 2007 tentang Perseroan Terbatas

(Lembaran Negara Republik Indonesia Tahun

2007 Nomor 106, Tambahan Lembaran

Negara Republik Indonesia Nomor 4756).

Undang-Undang Republik Indonesia Nomor 4

Tahun 2009 tentang Pertambangan Mineral

dan Batubara (Lembaran Negara Republik

Indonesia Tahun 2009 Nomor 4, Tambahan

Lembaran Negara Republik Indonesia Nomor 4959).

Peraturan Pemerintah Republik Indonesia Nomor 23

Tahun 2005 tentang Pengelolaan Keuangan

Badan Layanan Umum (Lembaran Negara
Republik Indonesia Tahun 2005 Nomor 48, Tambahan Lembaran Negara Republik Indonesia Nomor 4576).

Peraturan Pemerintah Republik Indonesia Nomor 58 Tahun 2005 tentang Pengelolaan Keuangan Daerah (Lembaran Negara Republik Indonesia Tahun 2005 Nomor 140, Tambahan Lembaran Negara Republik Indonesia Nomor 4578).

Peraturan Pemerintah Republik Indonesia Nomor 50 Tahun 2007 tentang Tata Cara Pelaksanaan Kerja Sama Daerah (Lembaran Negara Republik Indonesia Tahun 2007 Nomor 112, Tambahan Lembaran Negara Republik Indonesia Nomor 4761).

Peraturan Daerah Nomor 4 Tahun 2010 tentang Perseroan Terbatas Daerah Maju Bersaing (Lembaran Daerah Provinsi Nusa Tenggara Barat Tahun 2010 Nomor 27, Tambahan Lembaran Daerah Nomor 57).

\section{Dokumen Lainnya}

Kontrak Karya antara Pemerintah RI dan PT NNT tanggal 2 Desember 1986.

Perjanjian Kerjasama antara Gubernur NTB, Bupati Sumbawa Barat dan Bupati Sumbawa Nomor 415.4/229/KESDA, Nomor 500/70/ EKBANG/2009, Nomor 21 Tahun 2009 tentang Pendirian Perusahaan Patungan.

Multilateral Agreement on Investment.

Energy Charter Treaty. 